\title{
Discurso político, ethos e legitimidade: uma análise de discursos de posse do governo Bolsonaro
}

\section{Political discourse, ethos and legitimacy: an analysis of Bolsonaro's government inaugural speeches}

\section{Discurso politico, ethos y legitimidad: un análisis de los discursos de posesión del gobierno de Bolsonaro}

\author{
Jéser Abílio de Souza ${ }^{a}$ @, Marcus Leite ${ }^{\mathrm{b}}$ \\ a Mestre em Ciência Política pelo Programa de Pós-Graduação em Ciência Política da Universidade Federal de Minas Gerais. Bacharel \\ em Direito pela Universidade Paulista. Bacharel em Relações Internacionais pela Faculdade de Ciências Humanas e Sociais da Univer- \\ sidade Estadual Paulista. Pesquisador integrante do Grupo de Pesquisa "Núcleo de Estudos Linguísticos e Culturais" da UNESP/CNPq. \\ Áreas de atuação: Política Internacional, Política Externa, Representação de Identidade e Análises do Discurso. \\ E-mail: jeser_asouza@hotmail.com \\ ${ }^{\mathrm{b}}$ Mestrando e bacharel em Direito pela Universidade Federal de Minas Gerais, na linha de pesquisa Direitos Humanos e Estado Demo- \\ crático de Direito: fundamentação, participação e efetividade. E-mail: marcusvftl@gmail.com
}

\begin{abstract}
Resumo: O trabalho tem o objetivo de compreender a constituição e a representação do ethos do governo Bolsonaro mediante a análise dos discursos de posse do atual Presidente e de quatro ministros de seu governo. A partir da análise do discurso, verificamos que os discursos combinam estratégias discursivas que buscam produzir efeitos de persuasão no destinatário, ao passo que tecem a legitimidade do governo e induzem a oposição, a acusação e a polarização político ideológica perante o adversário. Concluímos que os discursos constituíram e representaram o ethos do governo através de apelos religiosos, narrativas maniqueístas e de diversos elementos de cunho nacionalista, a fim de legitimar o poder e a dominação sobre a esquerda política.
\end{abstract}

Palavras-chave: ethos; discursos de posse; Análise do Discurso; estratégias discursivas.

Abstract: The paper aims to understand the constitution and the representation of the Bolsonaro's government ethos by analysing the inaugural speeches of President Jair Bolsonaro and of four ministers who compose his government. From Discourse Analysis, we found that these speeches combined discursive strategies that seek to produce persuasive effects on the recipient, while constructing the government's legitimacy and inducing opposition, accusation and political-ideological polarization towards the adversary. We concluded that these speeches have built and have represented the government's

Como citar o artigo: SOUZA, J.A.; LEITE, M. Discurso político, ethos e legitimidade: uma análise de discursos de posse do governo Bolsonaro. Revista de Ciências Humanas, Florianópolis, v. 54, 2020 DOI: 10.5007/21784582.2021.e73829 você pode compartilhar, adaptar, para qualquer fim, desde que atribua a autoria da obra, forneça um link para a licença, e indicar se foram feitas alterações. 
ethos through religious appeals, Manichaean narratives and several elements of nationalist nature, in order to legitimize the government's power and domination over the Other, the political left.

Keywords: ethos; inaugural speeches; Discourse Analysis; discursive strategies.

Resumen: El trabajo tiene como objetivo comprender la constitución y la representación del espíritu del gobierno de Bolsonaro analizando los discursos inaugurales del actual presidente y cuatro ministros de su gobierno. Del análisis del discurso, comprobamos que los discursos combinan estrategias discursivas que buscan producir efectos persuasivos en el receptor, mientras tejen la legitimidad del gobierno e inducen oposición, acusación y polarización política ideológica hacia el adversario. Concluimos que los discursos constituyeron y representaron el espíritu del gobierno a través de de apelaciones religiosas, narrativas maniqueas y diversos elementos de carácter nacionalista, con el fin de legitimar el poder y dominación sobre la izquierda política.

Palabras clave: ethos; discursos inaugurales; Análisis del discurso; estrategias discursivas.

\section{INTRODUÇÃO}

Em 2018, o Brasil vivenciou um cenário político em que as eleições presidenciais foram definidas por uma acentuada polarização político-ideológica entre a direita e a esquerda. De um lado, encontrava-se a campanha de Jair Bolsonaro, candidato do Partido Social Liberal (PSL) e pertencente ao espectro político-ideológico da direita, e, de outra parte, estavam certas pautas consideradas como de esquerda - representadas especialmente pelos projetos políticos do Partido dos Trabalhadores (PT), do Partido Socialismo e Liberdade (PSOL) e do Partido Democrático Trabalhista (PDT). O presidente eleito tem se apoiado em uma plataforma regressiva em termos de direitos humanos e de minorias, defendendo práticas e políticas do regime ditatorial-militar, valores do ultraconservadorismo e do (neo) liberalismo econômico e discursos anticomunistas e moralistas adjunto ao de políticos evangélicos (CODATO; BERLATTO; BOLOGNESI, 2018). Nesse sentido, Solano (2019a; 2019b) aponta que a retórica eleitoral de Bolsonaro se apoiou fortemente em um "antiesquerdismo raivoso" por meio de uma política dos antagonismos, havendo uma rejeição de alteridades ao mobilizar raivas, angústias e valores para que aquele o adversário político, a esquerda, fosse aniquilado.

Considerando esse quadro, é preciso compreender o processo de legitimação da imagem do governo perante o público. Conforme explica Charaudeau (2018), a legitimidade incide no estado ou na qualidade daquele cuja ação é bem fundamentada, depende do reconhecimento de um sujeito por outros e é realizada em nome de um valor aceito por todos. A legitimidade é importante no cenário político porque é ela que "dá a toda instância da palavra uma autoridade de dizer" (CHARAUDEAU, 2018, p. 65). Uma das maneiras de compreender como o governo se torna legítimo por meio da palavra é pela análise do ethos. Para a Análise do Discurso, o ethos tem sido entendido como a imagem discursiva do próprio sujeito enunciador (e não de outrem) que é constituída no/pelo discurso, não se tratando, assim, de um indivíduo "real", mas de um ponto de vista discursivo que orienta um modo de presença do sujeito enunciador no mundo.

Diante disso, esta análise é guiada pelas seguintes perguntas: de que maneira o ethos do governo Bolsonaro foi constituído e representado pela base do alto escalão no início de sua gestão? Como esse ethos contribuiu discursivamente para conferir legitimidade ao mesmo? Sendo assim, o objetivo deste artigo é identificar e analisar como o ethos do governo Bolsonaro foi constituído em discursos políticos proferidos por certos representantes durante a posse de seus cargos para o alto escalão do governo. Como arcabouço teórico-metodológico, este trabalho se pauta em uma Análise do Discurso que combina contribuições teóricas de Dominique Maingueneau e de Patrick Charaudeau acerca do ethos; e da aplicação do dispositivo de análise da Semântica Global, elaborado por Maingueneau (2016).

Partimos da premissa de que os discursos de posse no governo Bolsonaro combinaram estratégias discursivas para a desconstrução do outro, o adversário, por meio da constituição e representação de 
específicos ethé (plural da palavra ethos) do governo, sendo que tais estratégias, por um lado, buscaram obter legitimidade diante de relações de poder presentes na disputa por espaço político, e, por outro, induziram e potencializaram a oposição, a acusação e a polarização político-ideológica mediante a adoção de certos posicionamentos discursivos e ideológicos. Isso se deve ao fato de que, desde as eleições presidenciais, os discursos da campanha de Bolsonaro categorizaram fortemente a esquerda e seus representantes como inimigos da nação e do povo.

A relevância do tema recai justamente sobre compreender como o discurso político é uma questão de poder, de modo a construir uma "realidade" mediante estratégias discursivas que operam sentidos, ao passo que desconstrói os adversários/oponentes e busca persuadir a população, os cidadãos, em prol de valores e objetivos que o governo estabelece. Centralizar a análise no ethos coletivo (e não no ethos individual de cada representante político) é tomar que a ação política, no espaço público-estatal, é orientada pelo governo, como se houvesse uma "unidade" através da palavra política na instância estatal. Assim, o ethos perfaz uma estratégia do discurso político, produzindo efeitos que podem influenciar uma sociedade a fim de consolidar e retificar ações e políticas, assim como dissimular polêmicas e evitar críticas. Logo, é importante a análise da temática proposta por compreendermos que a linguagem se encontra presente no desenrolar da própria ação política, determinando e organizando a vida social (CHARAUDEAU, 2018).

\section{DISCURSO POLÍTICO COMO ESPAÇO DE LUTA PELO PODER: ELUCIDANDO ALGUNS ELEMENTOS}

Maingueneau $(2013 ; 2015)$ define o discurso como uma manifestação da linguagem, sendo assumido por um sujeito que se coloca como fonte de referências e que possui uma forma de ação sobre o outro (como se direcionar para alterar uma situação, ou sugerir, perguntar, se opor etc.). A respeito desse conceito, dois pontos importantes sobre o sujeito merecem destaque. Primeiro, esse sujeito, o enunciador, não equivale ao indivíduo de "carne e osso", mas àquele que "fala" a partir de uma posição marcada no campo discursivo, de modo que se define tão somente em relação a um determinado outro. O segundo ponto consiste na compreensão de que o sujeito discursivo sempre busca fazer com que esse outro pense, diga ou aja conforme a "intenção" daquele, ou seja, o discurso segue o princípio da influência (CHARAUDEAU, 2018). Isso não significa afirmar que os sentidos manifestados no discurso são essencialmente aquilo que foi planejado pelo sujeito enunciador. Os sentidos do discurso tanto emanam de um contexto específico (social, político, econômico) quanto contribuem para definir e modificar o próprio contexto.

Todos os elementos supramencionados são de suma importância quando analisamos o discurso político. De acordo com Charaudeau (2018), não existe política sem discurso, uma vez que a linguagem motiva, orienta e atribui sentido à ação política. Assim, ação política e discurso político se encontram vinculados, de modo que o primeiro se inscreve nas relações de influência social, enquanto o segundo permite que se constituam os espaços discursivos para discussão, por exemplo, de onde se elabora o pensamento e a ação política (CHARAUDEAU, 2018). A ação política perfaz as ações conjuntas para determinar e organizar a vida social ante a obtenção de um bem comum, pressupondo, por efeito, um espaço de discussão para que os objetivos sejam definidos, um modo de acesso à representação do poder (eleições) e modalidades de controle de poder no âmbito das instituições (CHARAUDEAU, 2018). Consequentemente, entendemos que para a ação política obter legitimidade - entre os pares no governo e pela sociedade - é necessário que os representantes políticos logrem ter uma influência social. Isso ocorre à medida que consideram o outro (a oposição, os demais partidos, os cidadãos, a mídia) para definir os meios e conseguir um resultado positivo. Diante disso, o princípio da influência possui uma enorme significância no discurso político.

Por sua vez, denomina-se discurso político a manifestação tanto de um sistema de pensamento em que se procura fundar um ideal político em face de determinados princípios de referência para a construção de posicionamentos e opiniões, quanto um ato de comunicação pautado na interação entre os atores que 
participam da cena de comunicação política a fim de influenciar as opiniões (CHARAUDEAU, 2018). Os discursos políticos têm distintos locais de enunciação, como o Parlamento, a imprensa e também a sociedade civil (PINTO, 2005). No caso desse artigo, analisamos o discurso político que configura a política do Estado.

Um elemento que se destaca no discurso político é a questão do poder, porque este tipo de discurso explicita uma luta pelo poder entre relações de força que os sujeitos mantêm entre si, ao passo que, de um lado, busca impor visões de um mundo e, de outro, opera através da desconstrução ou anulação do outro mediante a polêmica (PINTO, 2006). A polêmica, para fins dessa análise, trata do modo pelo qual os discursos polemizam ao incluir o outro através de um simulacro que se cria por meio de fragmentos de enunciados localizáveis, de modo a haver, assim, uma citação de tais fragmentos, com o propósito de anular esse outro (MAINGUENEAU, 2016), considerando-o como ameaça, corpo estranho ou inferior. Isto posto, há uma disputa pelo espaço político. Desconstruir o outro é uma condição essencial para construir a si próprio no discurso político (PINTO, 2006). Assim, a questão do poder no discurso político incide no "agir sobre o outro" (CHARAUDEAU, 2016, p. 14), já que este tipo de discurso tem uma tendência a descontruir ou anular o outro. Entretanto, é necessário que esse "agir sobre o outro" seja justificado, e, nesse caso, coloca-se a questão da legitimidade, de maneira que o discurso político também opera reivindicando o monopólio da legitimidade para si a fim de justificar o direito que se tem de agir na relação de dominação (CHARAUDEAU, 2016).

Ainda sobre a questão do poder, no domínio de um governo, o poder político resulta do debate de ideias no espaço público e do fazer político onde se tomam decisões e se estabelecem atos, conforme as relações de forças que caracterizam um jogo de dominação (CHARAUDEAU, 2018). Charaudeau (2018) explica que, na esfera do debate de ideias, a linguagem domina, pois é o local de uma luta discursiva em que são permitidas manipulações, ameaças, promessas. Por sua vez, na esfera do fazer político, a ação política domina, haja vista que é o lugar onde se exerce o poder de agir e da autoridade por meio da dominação. No domínio da nossa análise, centraremos na esfera privilegiada da linguagem, do discurso político, em que se fazem presentes as lutas de posicionamento discursivo, a instalação da polêmica e a constituição do ethos discursivo do governo, embora ela por si só já seja uma ação política que contribui para estabelecer e organizar a vida social.

\section{ETHOS: DE COMPLEXA NOÇÃO DISCURSIVA À ESTRATÉGIA DO DISCURSO POLÍTICO}

A concepção de ethos remonta a Aristóteles, que a define como a construção da imagem de si que o orador elabora no seu discurso destinada a garantir sucesso no empreendimento oratório: causar boa impressão, transmitir confiança e convencer o público (AMOSSY, 2005; MAINGUENEAU, 2014). Entretanto, a noção de ethos possui diversas facetas, e cada disciplina das Ciências Humanas tem um interesse particular e distinto para apreendê-la. Nesse artigo, o que nos interessa é a compreensão de ethos para o campo dos estudos do discurso, de forma que o desenvolvimento desta noção tem sido atrelado ao ato de enunciação.

Diante disso, dentro de um quadro de Análise do Discurso, o ethos discursivo incide sobre o "uso de elementos linguísticos pelo enunciador para a construção da imagem de si no ato enunciativo" (SILVEIRA, 2014, p. 18). No entanto, não se pode desconsiderar que o destinatário contribui para a constituição do ethos do enunciador. Consoante a Maingueneau (2012; 2014), o ethos discursivo não equivale a uma imagem do locutor exterior a sua fala, mas é construído por meio do discurso, ao passo que se funda em um processo interativo de influência sobre o destinatário. Desse modo, o ethos discursivo se manifesta no discurso, sendo que a instância subjetiva emerge da enunciação ao encarnar uma voz associada a certo corpo enunciante em uma conjuntura (social, política, ideológica etc.) historicamente especificada. Este ethos do enunciador depende, ainda, do olhar avaliativo do destinatário. Isso porque, mundos éticos são invocados pela enunciação, trazendo estereótipos ligados 
a um conjunto difuso de representações em torno do ethos, e o destinatário colabora para confrontar ou transformar tais estereótipos (MAINGUENEAU, 2010; 2012; 2014).

Esse modo de o interpretante/destinatário atribuir significados ao ethos do enunciador, ao passo que avalia positiva ou negativamente o conjunto de representações perante um mundo ético ativado na enunciação, é concebido como incorporação. A incorporação, na perspectiva de Maingueneau (2012; 2013; 2014), consiste no processo de designar a ação do ethos sobre o destinatário, haja vista que esse não apenas identifica, mas incorpora e assimila aquele conjunto de representações estereotipadas que definem determinado sujeito pela maneira específica de se remeter ao mundo; como a enunciação dá um corpo, ela conduz o destinatário a conferir um ethos a ele. Em virtude da sua contribuição para a construção do ethos do enunciador, o destinatário é também chamado de coenunciador.

A noção em questão ganha complexidade quando distinguimos o ethos dito do ethos mostrado. De acordo com Maingueneau (2012; 2014), o ethos dito refere-se aos fragmentos do texto que o enunciador evoca para dizer sobre si mesmo, seja de forma direta ou indiretamente (por meio de metáforas ou referência a outros contextos de fala); enquanto o ethos mostrado concerne àquilo que se mostra na maneira de enunciar através do tom e das escolhas linguísticas do discurso. Trata-se de um ethos percebido pelo leitor. Sobre o tom, Maingueneau $(2012 ; 2013)$ o descreve como a forma pela qual o enunciador atesta o seu dizer atribuindo uma autoridade ao que é dito no seu discurso, seja no texto escrito ou oral, permitindo que o destinatário construa a representação do corpo e do caráter do tal enunciador. O caráter, por sua vez, corresponde aos traços psicológicos do enunciador e à corporalidade que está associada subjetivamente às propriedades físicas e à maneira como o corpo se move no espaço social (MAINGUENEAU, 2012; 2014).

Partindo da compreensão de que o ethos se apoia em um duplo imaginário corporal e moral, Charaudeau (2018) traz a noção de ethos coletivo. O ethos coletivo corresponde a uma visão global que é construída pela atribuição de uma identidade que emana de uma opinião coletiva em relação a outro grupo (CHARAUDEAU, 2018). Para se constituírem enquanto uma entidade homogênea, os grupos compartilham características similares entre os seus indivíduos, à medida que julgam os demais grupos com base em um traço de sua identidade (CHARAUDEAU, 2018). Dessa maneira, entendemos que os discursos políticos, em especial os discursos de posse, expressam uma opinião coletiva de um grupo político e institucional e, que, em razão dos diversos sujeitos enunciadores demarcados em tais discursos compartilharem uma mesma visão, o próprio ethos do governo Bolsonaro é constituído e representado, uma vez que eles mesmos são, nos discursos, parte do governo.

Ademais, como o destinatário contribui para a construção da representação do enunciador (ou locutor), esse último busca controlar na enunciação as maneiras como sua imagem possa ser constituída (MAINGUENEAU, 2010). Isso ocorre seja reforçando e consolidando atributos e estereótipos valorizados, seja desconstruindo e atenuando atributos e estereótipos desvalorizados. Por efeito, o poder de persuasão do discurso deriva, em grande parte, de como o destinatário é constrangido, pela enunciação, a se identificar e incorporar esquemas estereotípicos com o movimento de um corpo, seja esse esquemático ou investido de valores historicamente especificados (MAINGUENEAU, 2012).

Esse poder de persuasão atrelado ao ethos é extremamente importante quando centramos nos discursos políticos, tendo em vista que a relação com o outro é essencial para esse tipo de discurso com a finalidade de viabilizar decisões e atos políticos mediante a obtenção de legitimidade e da construção de opiniões. Consequentemente, os discursos políticos recorrem a muitas estratégias discursivas que visam a persuadir o maior número de indivíduos. A partir da perspectiva de Charaudeau (2014), concebemos estratégias discursivas como as formas como o sujeito enunciador estabelece, organiza e encena certas "intenções" na produção de determinados efeitos de persuasão sobre o sujeito interpretante, de modo que esse último seja levado a se identificar com aquilo que foi construído por aquele enunciador.

Outro conjunto de estratégias é a nossa compreensão acerca do estabelecimento nos/pelos discursos de comportamentos de oposição, acusação e polarização político-ideológica, tendo o objetivo em promover uma desconstrução e/ou uma anulação do outro. A oposição deriva da marcação de diferenças 
radicais passíveis de comparação entre os sujeitos discursivos, como diferenças entre valores, estados, naturezas etc. A acusação incide na atribuição de culpa ou responsabilidade por algo, fenômeno ou evento, em relação aos outros sujeitos, que nesse artigo são denominados de adversários. Finalmente, a polarização político-ideológica consiste na instalação e na concentração de extremos opostos, esses pautados no espectro político entre direita e esquerda (e suas ramificações) e seus valores e pautas defendidas, de forma que o sujeito enunciador posiciona e instiga um grupo (o destinatário, o público) a pensar e agir em relação aos outros (os adversários/oponentes). A constituição e representação do ethos pode não só abarcar todas essas estratégias discursivas como pode, ele mesmo, ser compreendido enquanto uma estratégia discursiva, desempenhando essas distintas ações discursivas (influenciar, persuadir, acusar, se opor e polarizar) instaladas e instigadas no discurso político.

\section{PERCURSO METODOLÓGICO: DELINEANDO UM MÉTODO DE ANÁLISE DE DISCURSO PARA A INVESTIGAÇÃO DO ETHOS EM DISCURSOS DE POSSE}

A análise da noção discursiva de ethos coletivo adotada nesse artigo utiliza uma metodologia com enfoque na interpretação dos sentidos advindos de posicionamentos discursivos e ideológicos que constituíram e representaram o ethos do governo Bolsonaro. Em face disso, é necessário informar que não se busca conduzir a análise do discurso como uma abordagem de cunho psicológico que tenta entender os pensamentos dos indivíduos ou planos ocultos do governo. Qualquer "demonstração psicológica" atrelada ao ethos do enunciador não corresponde ao estado psicológico real dele (CHARAUDEAU, 2018), mas sim representa os efeitos de sentidos impostos pelos posicionamentos discursivos (MAINGUENEAU, 1997).

Valendo-se dos conceitos discutidos nas seções anteriores, o discurso de posse, na modalidade textual, compreende o nosso corpus de análise. Entendemos por discurso de posse o pronunciamento de um representante político no momento de retificação da legitimidade de um poder conquistado mediante determinada plataforma política que é exposta e dirigida à população (DEBERT, 2008). Posto isso, o discurso de posse é um tipo específico de discurso político e não se encontra despido de estratégias discursivas.

A escolha desse tipo de discurso como material de análise reside em três razões: a) adotar o discurso de posse como objeto de análise é buscar examinar como a legitimação do poder tem se atrelado a imagem do governo constituída por ele próprio nos discursos em seu primeiro momento de ação político-estatal diante das polêmicas e críticas que surgiram com a campanha de Bolsonaro durante as eleições presidenciais; b) no discurso de posse há (ou se espera que haja) um relato amplo do projeto político do governo, facilitando a identificação de valores gerais da ação político-estatal; e c) centralizando nesse gênero discursivo, conseguimos garantir homogeneidade em relação à emissão dos discursos, ainda que cada um dos discursos de posse tenha sua especificidade.

Nesta análise, os discursos de posse utilizados consistem naqueles pronunciamentos realizados por representantes da base do alto escalão logo no início do governo em questão, sendo que os textos escolhidos compõem os discursos do próprio presidente da República, Jair Bolsonaro, incluindo os seus pronunciamentos no Congresso Nacional e no Palácio do Planalto. Além disso, analisamos os discursos dos seguintes ministros: Damares Alves, a ministra da Mulher, da Família e dos Direitos Humanos; Sérgio Moro, ministro da Justiça e Segurança Pública; Ernesto Araújo, ministro das Relações Exteriores; e Ricardo Vélez Rodríguez, ministro da Educação. A escolha dos discursos alicerçada nestes sujeitos se justifica pela ampla popularidade desses representantes na sociedade brasileira, já que seus nomes e discursos são veiculados constantemente na imprensa e nas mídias sociais.

No tocante ao método de análise do discurso, apoiamo-nos no dispositivo denominado de Semântica Global, elaborado por Dominique Maingueneau na obra Gênese dos Discursos (2016). Partindo do postulado de que o interdiscurso precede o discurso, Maingueneau propõe um procedimento de análise que toma para si os planos discursivos para apreender o discurso, tendo em vista que tais planos são restringidos por um "sistema de restrições semânticas globais" (2006, p. 22). Dentre os planos discursivos propostos pelo 
linguista francês, tomamos o vocabulário, os temas, os estatutos do enunciador e do destinatário (e também do adversário, explicação abaixo) e a intertextualidade como as categorias linguístico-discursivas para a análise. Como todo discurso possui vocabulário, tema e enunciador, essas categorias foram escolhidas juntamente com a intertextualidade, de maneira que essa última trata de um esforço de encontrar e estabelecer links com tipos distintos de discursos à medida que se identifica os fragmentos desses outros discursos (políticos ou não) que possam ser trazidos no contexto dos discursos de posse.

Na categoria vocabulário, parte-se para a identificação e a análise de certas palavras que marcam posições no discurso, de modo que determinados termos podem cristalizar pontos semânticos no mesmo pela forma como são utilizados ou pela sua repetição (MAINGUENEAU, 2016). Cumpre apontar que o vocabulário, enquanto categoria explorada pela análise de discurso na teoria de Maingueneau, não pode ser analisado em separado de outras categorias e elementos discursivos de um corpus, pois pouco revela sobre as construções discursivas e interpretações que possam ser realizadas.

Com a categoria temas, buscamos observar não somente do que se trata o discurso por meio dos valores com os quais a ação política busca satisfazer o desejo de viver em comunidade (CHARAUDEAU, 2018), mas também como os temas se estabelecem. Nesse âmbito, um grupo de temas é denominado de impostos (MAINGUENEAU, 2016). Ao fazer alusão ao discurso político-eleitoral, Maingueneau esclarece que os temas impostos consistem na imposição de determinado número de temas obrigatoriamente por todo discurso a fim de ser aceito, como "ampliação das liberdades, segurança dos cidadãos, qualidade de vida" (2016, p. 84), dentre outros. Esses temas impostos dividem-se em compatíveis e incompatíveis: os primeiros se referem à convergência de temas com o sistema de restrições semânticas, enquanto os segundos, embora integrados, não convergem.

No que se refere à intertextualidade, buscamos apreender os tipos de relações intertextuais que o discurso define como legítimas ao fazer referência a discursos anteriores, quer se filiando ou recusando certos posicionamentos discursivos (MAINGUENEAU, 2016). A intertextualidade difere do intertexto, sendo esse definido como o conjunto de fragmentos que um discurso cita efetivamente (MAINGUENEAU, 2016).

Por fim, sobre a última categoria, Maingueneau (2016) explica que os discursos definem os estatutos que tenham sido conferidos ao enunciador e o que foi atribuído ao destinatário a fim de legitimar o seu dizer. Esse processo possui duas dimensões: uma institucional e outra intertextual. Estamos considerando, como estatuto do enunciador, o do governo e, como estatuto do destinatário, o público específico que o enunciador visa a persuadir, como o povo no domínio de um discurso político. Ressalta-se, assim, que não tomaremos os sujeitos enunciadores enquanto presidente e ministros, pois estamos preocupados com o estatuto coletivo dentro do plano do ethos coletivo; não temos a intenção de analisar o ethos desses distintos representantes. Realizamos, ainda, uma modificação nessa categoria, de modo que, além de analisar os estatutos do enunciador e do destinatário, também olharemos para a atribuição do estatuto do sujeito adversário, pois sendo o discurso de posse o primeiro pronunciamento oficial de um governo que conquista o poder, é necessário analisar como a imagem do enunciador (o governo) se define em relação ao adversário, os sujeitos vencidos nas eleições, isto é, o outro.

Ressalta-se, ainda, que o enfoque dado aos trechos analisados justifica-se pela percepção de elementos comuns presentes nos diferentes discursos estudados (de modo a constituir o ethos), embora cada um deles contenha também outros aspectos que poderiam ser considerados igualmente relevantes para outras formas de análise.

\section{A LIBERTAÇÃO DA "TERRA PROMETIDA": O MANIQUEÍSMO RELIGIOSO- CRISTÃO ENTRELAÇADO COM O CAMPO POLÍTICO NACIONALISTA}

Pela análise do vocabulário, com exceção do discurso de posse do ministro Sérgio Moro, todos os demais vieram marcados por elementos vocabulares com referências bíblicas e religiosas. Observam-se os excertos abaixo: 
Não podemos deixar que ideologias nefastas venham a dividir os brasileiros. Ideologias que destroem nossos valores e tradições, destroem nossas famílias, alicerce da nossa sociedade. [...] Peço ao bom Deus que nos dê sabedoria para conduzir a nação.

Que Deus abençoe esta grande nação. (BRASIL, BOLSONARO, 2019a, grifo nosso)

Vamos unir o povo, valorizar a família, respeitar as religiões e nossa tradição judaico-cristã (...)

[...] quando os inimigos da pátria, da ordem e da liberdade tentaram pôr fim à minha vida, milhões de brasileiros foram às ruas.

[...] Uma campanha eleitoral transformou-se em um movimento cívico, cobriu-se de verde e amarelo, tornou-se espontânea, forte e indestrutível, e nos trouxe até aqui.

(BRASIL, BOLSONARO, 2019b, grifo nosso)

À agressiva promoção da ideologia de gênero somou-se a tentativa de derrubar as nossas mais caras tradições pátrias. Essa tresloucada onda globalista, tomando carona no pensamento gramsciano e num irresponsável pragmatismo sofístico, passou a destruir, um a um, os valores culturais em que se sedimentam as nossas instituições mais caras: a família, a igreja, a escola, o estado e a pátria, numa clara tentativa de sufocar os valores fundantes da nossa vida social. [...] Trata-se de uma ideologia materialista, alheia aos nossos mais caros valores de patriotismo e de visão religiosa do mundo.

[...] Que Deus nos ajude nesta empreitada e que possamos honrar o compromisso que, neste momento, assumimos com o nosso país! (NOVA ESCOLA, RODRÍGUEZ, 2019, grifo nosso)

O presidente Bolsonaro disse que nós estamos vivendo o momento de uma nova Independência. [...] Nós temos tradições, é claro, mas precisamos empregá-las como estímulo para buscar a verdade e a liberdade, como serviço à pátria, como serviço a todos os brasileiros, tanto os mais humildes, quanto os mais afortunados do nosso povo, esse povo que uma ideologia perversa não mais divide.

[...] isso aqui não é simplesmente uma repartição pública, isso aqui é uma espécie de um santuário.

[...] Por isso a luta pela nação é a mesma luta pela família e a mesma luta pela vida, a mesma luta pela humanidade em sua dignidade infinita de criatura.

[...] O presidente Bolsonaro está libertando o Brasil, por meio da verdade.

[...] Tudo o que temos, tudo de que precisamos, é a palavra. Ela está aprisionada, mas com amor e com coragem havemos de libertá-la.

[...] Que Deus abençoe o presidente Jair Bolsonaro e que Deus abençoe o Brasil.

(BRASIL, ARAÚJO, 2019, grifo nosso)

[...] Um dos desafios desse atual governo é acabar... uau, com o abuso da doutrinação ideológica. Trabalharemos junto com o poder público para construir um Brasil em que nossas crianças tenham acesso à verdade e sejam livres para pensar. Acabou a doutrinação ideológica de crianças e adolescentes no Brasil. (TV BRASILGOV, ALVES, 2019, grifo nosso)

Primeiramente, o conjunto de vocábulos Deus, família, valores, Palavra e verdade que marca uma posição de aliança com o governo. Essa relação de aliança é evidente pelo uso corrente desses vocábulos que qualificam o governo, como ao apontar que o governo irá "valorizar a família" e "respeitar as tradições", que possui uma "visão religiosa do mundo", que segue uma "tradição judaico-cristã" e suplica "ao bom Deus". Tais expressões, que carregam uma carga semântica positiva, acabam acionando nos textos ideias de devoção e de apreço pelo governo. Entretanto, além da relação de aliança desse conjunto de vocábulos de cunho religioso-cristão com o governo, há, ainda, o entrelaçamento dele com expressões que trazem ideias do campo político nacionalista, como o uso recorrente dos vocábulos pátria, nação e liberdade e o aparecimento de expressões que denotam esse sentido, como as expressões "nos braços do povo", "movimento cívico" coberto de "verde e amarelo", "valores do patriotismo", "nova Independência", "tradições pátrias" e muitas outras.

Além disso, termos como "luta pela família", "luta pela nação", "inimigos da pátria", "libertando o Brasil por meio da verdade" e "havemos de libertá-la [palavra]" articulam a ideia que o governo 
está enfrentando uma batalha. Nesse quesito, relaciona-se o segundo conjunto de vocábulos, centrado no termo ideologia. Com carga semântica negativa, o termo ideologia aparece em oposição àquele primeiro conjunto que é valorizado nos textos. Expressões como "ideologias nefastas", "ideologias perversas", "ideologias que destroem", "abuso de doutrinação ideológica", "ramificações ideológicas e seus instrumentos contrários à nação".

A recorrência desses vocábulos de ordem religiosa e de cunho nacionalista não é suficiente para dizer qual ethos coletivo que se está constituindo apenas por uma análise isolada do vocabulário. É preciso adotar estes fragmentos de vocabulário analisados como marcadores e sinalizadores discursivos e interagirem eles com as demais categorias. A análise do vocabulário já sinaliza dois elementos importantes nesses textos: a) as relações textuais definidas como legítimas nos discursos de posse foram constituídas, principalmente, entre o campo político nacionalista e o campo religioso-cristão; e b) tais relações textuais estabelecem uma oposição entre o governo e a ideologia. No entanto, a exceção a esta lógica é o discurso proferido pelo ministro Sérgio Moro: o único texto do corpus que não demonstra uso de vocábulos tipicamente de um posicionamento discursivo religioso e nacionalista. A carga semântica dos discursos de Moro é majoritariamente centrada em termos como corrupção e crime - outro tema que é compartilhado por diferentes ministros.

Direcionando a atenção para os temas, particularmente os impostos, eles se mostram compatíveis semanticamente com: a) os valores do governo, sendo o combate à corrupção e à criminalidade, com forte apelo à segurança, como por exemplo, expressados nas passagens, "a corrupção, os privilégios e as vantagens precisam acabar", "missão prioritária dada [...] foi claro, o fim da impunidade da grande corrupção", "missão de restaurar e de reerguer nossa pátria, libertando-a definitivamente, do julgo da corrupção, da criminalidade", e "ostensivo processo de corrupção" e "ao leiloar, na bacia das almas da corrupção indiscriminada" para se referir ao governo Lula; e, b) a defesa da liberdade, como liberdade econômica, liberdade de ir e vir, liberdade de expressão etc. Eles são, por sua vez, também pertencentes a um quadro conservador, já que tais temas se entrelaçam com aqueles valores de cunho religioso-cristão, defesa da família, tradições e da religião, expressados pelos vocábulos e expressões anteriormente apresentados.

Acorrupção, os privilégios e as vantagens precisam acabar. Os favores politizados, partidarizados devem ficar no passado, para que o Governo e a economia sirvam de verdade a toda a Nação. $[\ldots]$

Nossa preocupação será com a segurança das pessoas de bem e a garantia do direito de propriedade e da legítima defesa, e o nosso compromisso é valorizar e dar respaldo ao trabalho de todas as forças de segurança. (BRASIL, BOLSONARO, 2019a, grifo nosso)

[...] que sonham com a liberdade de ir e vir, sem serem vitimados pelo crime; que desejam conquistar, pelo mérito, bons empregos e sustentar com dignidade suas famílias; (...) [...] Aproveito este momento solene e convoco cada um dos congressistas para me ajudarem na missão de restaurar e de reerguer nossa pátria, libertando-a, definitivamente, do jugo da corrupção, da criminalidade, da irresponsabilidade econômica e da submissão ideológica. (BRASIL, BOLSONARO, 2019b, grifo nosso)

[...] Escutou de milhares de cidadãos queixas que ratificaram as percepções e $\underline{\text { ńndices }}$ alarmantes de criminalidade (...)

[...] o então candidato Bolsonaro ouviu dos empobrecidos contribuintes as queixas que tinham como origem o ostensivo processo de corrupção que, no ciclo lulopetista, dilapidou a riqueza nacional em balcões escusos de negócio. Ao leiloar, na bacia das almas da corrupção indiscriminada, os recursos da nação, tornou-se evidente o risco à sobrevivência das novas gerações (...)

(NOVA ESCOLA, RODRÍGUEZ, 2019, grifo nosso)

[...] Defenderemos a liberdade e a vida. Defenderemos o direito de cada povo de ser o que é, com liberdade e dignidade, com a dignidade que unicamente a liberdade proporciona. 
[...] Defenderemos a soberania. Defenderemos a liberdade - a liberdade de expressão, a liberdade de crença, a liberdade na internet, a liberdade política. (BRASIL, ARAÚJO, 2019, grifo nosso) Trabalharemos junto com o poder público para construir um Brasil em que nossas crianças tenham

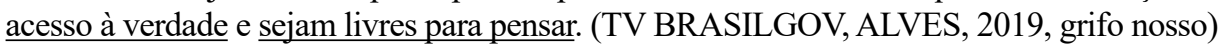

Nada disso será fácil, mas a missão prioritária dada pelo Sr. Presidente Jair Bolsonaro foi clara, o fim da impunidade da grande corrupção (...) (ESTADÃO, MORO, 2019, grifo nosso)

De maneira inversa, tais temas encontram-se em oposição ao termo ideologia. Observe os excertos abaixo.

Também é urgente acabar com a ideologia que defende bandidos e criminaliza policiais (...)

[...] Essa é a nossa bandeira, que jamais será vermelha.

(BRASIL, BOLSONARO, 2019a, grifo nosso)

(...) combater a ideologia de gênero, conservando nossos valores. O Brasil voltará a ser um país livre das amarras ideológicas. (BRASIL, BOLSONARO, 2019b, grifo nosso)

E por falar em vida, eu falo vida desde a concepção. Eu queria até que o Ministério que este nosso Ministério fosse chamado Mistério da Vida e da Alegria, mas não pode.

[...] E neste governo menina será princesa e menino será príncipe. Está dado o recado. (...) Ninguém vai nos impedir de chamar nossas meninas de princesas e nossos meninos de príncipe. No Brasil tem meninos e meninas.

(TV BRASILGOV, ALVES, 2019, grifo nosso)

O globalismo se constitui no ódio, através das suas várias ramificações ideológicas e seus instrumentos contrários à nação, contrários à natureza humana, e contrários ao próprio nascimento humano. (...) Aqueles que dizem que não existem homens e mulheres (...) são os mesmos que propalam que um feto humano é um amontoado de células descartável (...) (BRASIL, ARAÚJO, 2019, grifo nosso)

Jair Messias Bolsonaro também prestou atenção à voz entrecortada de pais e mães reprimidos pela retórica marxista que tomou conta do espaço educacional. À agressiva promoção da ideologia de gênero somou-se a tentativa de derrubar as nossas mais caras tradições pátrias.

[...] Essa tresloucada onda globalista, tomando carona no pensamento gramsciano e num irresponsável pragmatismo sofístico, passou a destruir, um a um, os valores culturais em que se sedimentam as nossas instituições mais caras: a família, a igreja, a escola, o estado e a pátria, numa clara tentativa de sufocar os valores fundantes da nossa vida social.

[...] Combateremos com denodo o marxismo cultural hoje presente em instituições de educação básica e superior.

(NOVA ESCOLA, RODRÍGUEZ, 2019, grifo nosso)

O vocábulo ideologia vincula-se aos posicionamentos de esquerda, por exemplo: a) à ideologia de gênero, a partir de expressões "aqueles que dizem que não existem homens e mulheres" e "contrários à natureza humana", e pela utilização de metáforas, como "menina será princesa e menino será príncipe"; b) ao aborto, através das expressões "propalam que um feto humano é um amontado de células descartável", "contrários ao próprio nascimento humano" e "eu falo vida desde a concepção"; e c) a categorizações mais amplas que se referem ao campo político-ideológico da esquerda como "retórica marxista", "ideologia que defende bandidos [e] criminaliza policiais", "globalismo", "onda globalista", "marxismo cultural", "pensamento gramsciano". Enfim, temos uma expressão que claramente remete à uma oposição deste campo político-ideológico quando realiza uma referência à cor vermelha associada ao comunismo: "nossa bandeira, que jamais será vermelha".

Os temas impostos trazem fragmentos textuais que fazem referência a temas de discursos de posicionamento político-ideológico de direita ao passo que se associam ao governo, ou seja, são 
tratados como compatíveis ao seu sistema de restrições semânticas; e, ainda, introduzem temas de posicionamento político-ideológico de esquerda, que, embora interligados, são instituídos como incompatíveis ao governo, já que não convergem com o tratamento semântico privilegiado. Não obstante o embate dos temas impostos entre compatíveis e incompatíveis nos textos, nota-se que é um conflito perpassado pelo campo religioso, denotando que aqueles temas impostos compatíveis, ao articularem vocábulos e expressões deste campo, transmitem ideais e valores conservadores. Entretanto, assim como a categoria vocabulário, os temas, analisados isoladamente, não possuem a capacidade de dizer qual o ethos coletivo do governo Bolsonaro que está sendo constituído nestes textos; é preciso tomá-los como marcadores e sinalizadores discursivos e combiná-los com as outras categorias.

Nesse sentido, temos mostrado que as escolhas textuais adotadas marcaram, principalmente, um vocabulário que tem entrelaçado o campo político nacionalista, a partir de posicionamentos discursivos e ideológicos comuns aos discursos de direita, com o campo religioso-cristão. Essa relação é intertextual e interage com os diversos estatutos dos sujeitos discursivos, cabendo, dessa forma, uma análise de como a intertextualidade e os estatutos dos sujeitos se relacionam nestes textos para a construção de determinados sentidos. É de se ressaltar, novamente, que, com exceção do discurso do ministro Sérgio Moro, todos os demais recorrem à construção e à representação de uma típica narrativa dos textos bíblicos com um tom nacionalista.

[...] o povo começou a se libertar do socialismo, se libertar da inversão de valores, do gigantismo estatal e do politicamente correto.

[...] Vamos promover as transformações que o País precisa. Temos recursos minerais abundantes, terras férteis abençoadas por Deus e por um povo maravilhoso.

(BRASIL, BOLSONARO, 2019a, grifo nosso)

Alguns parlamentares que sonharam comigo, este novo tempo para o Brasil. (...) olha onde o nosso sonho nos trouxe... um Brasil novo no momento novo para essa nação.

[...] Temos a garantia de nosso Presidente da República de que as brasileiras terão voz e serão escutadas por esse novo e restaurador governo que se inicia.

(TV BRASILGOV, ALVES, 2019, grifo nosso)

“Conhecereis a verdade e a verdade vos libertará". Essa convicção íntima e profunda animou o presidente Jair Bolsonaro na luta extraordinária que ele travou e está travando para reconquistar o Brasil e devolver o Brasil aos brasileiros.

[...] O presidente Bolsonaro está libertando o Brasil, por meio da verdade.

[...] Para destruir a humanidade é preciso acabar com as nações e afastar o homem de Deus, e é isso que estão tentando, e é contra isso que nos insurgimos.

[...] a teofobia, o ódio contra Deus. Há uma teofobia horrenda, gritante, na nossa cultura. Não só no Brasil, em todo o mundo. Um ódio contra Deus, proveniente sabe-se lá de onde, canalizado por todos os códigos de pensamento e de não-pensamento que perfazem a agenda global.

[...] Acreditemos no poder infinito da palavra, que é o logos criador.

O presidente Jair Bolsonaro está aqui, chegou até aqui, e nós com ele, porque diz o que sente. Porque diz a verdade. (BRASIL, ARAÚJO, 2019, grifo nosso)

Combateremos com denodo o marxismo cultural hoje presente em instituições de educação básica e superior.

[...] os mais ameaçados pela pregação moralizante em andamento urdiram obscuro plano para tirá-lo de vez da cena eleitoral, atentando contra a sua vida.

(NOVA ESCOLA, RODRÍGUEZ, 2019, grifo nosso)

O imaginário concebido nos discursos coloca o Brasil como "terras férteis abençoadas por Deus", mas que se encontra ocupado por inimigos ou invasores, uma vez que ao fazer uso das expressões "libertando o Brasil", "reconquistar o Brasil" e "devolver o Brasil", tem-se o pressuposto da existência de um outro indesejado, que nos textos tem sido atribuído ao "marxismo cultural", "socialismo", "globalismo", os "inimigos da pátria", e suas ideologias, ideologias essas representadas similarmente 
pela condição de pecado sendo que tal condição se dá em virtude dos textos considerarem-nas como nefastas, perversas, "destruidoras de valores, tradições e famílias" e "contrárias aos valores do patriotismo e à visão religiosa do mundo". Temos, assim, a consolidação de uma relação de oposição de posicionamentos pautada em um clássico maniqueísmo religioso do bem versus mal.

É importante notar que o campo discursivo religioso não é o único de uma relação intertextual que se apresenta nos textos analisados. No discurso de posse do ministro Ernesto Araújo, por exemplo, é possível verificar a intertextualidade através do campo discursivo filosófico, literário, da música e do cinema, enquanto que no discurso de posse do ministro Sérgio Moro, temos intertextualidade no campo jurídico. Contudo, o campo religioso foi o que mais esteve presente nos discursos de posse em conjunto, sendo que os outros campos se encontram isolados em um discurso de determinado enunciador. Nesse sentido, o que se observa de maneira é que o discurso do ministro Sérgio Moro foi aquele que mais destoa em termos de vocábulos utilizados e temas mobilizados, além da ausência de uma intertextualidade com o campo religioso-cristão, motivo pelo qual não se ativou a forte oposição entre bem e mal como os outros, tampouco formou uma narrativa de inspiração religiosa com exaltação à imagem nacional brasileira.

De toda forma, o outro (os inimigos e o pecado) é trazido neste corpus numa situação a ser combatido pela nação, pelo povo e pelo governo ("luta pela família"; "luta pela nação"). O estatuto do adversário é constituído na posição de inimigo, apresentando duas facetas. A primeira, na dimensão institucional, vincula o adversário à corrupção. Essa corrupção é referida ao passado, como na expressão "tornou o Estado ineficiente e corrupto", em que o verbo passar conjugado no passado julga certo sujeito, que no texto corresponde uma equipe com "tradicional viés político", responsável pela corrupção instalada no Estado; e no uso das expressões "devem ficar no passado" e "empreender esforços para acabar com ela" que invocam um imperativo do atual governo em alterar a situação da corrupção no Estado que fora despontado no passado; e, ainda, a citação direta ao governo Lula e ao Partido dos Trabalhadores quando traz "ostensivo processo de corrupção no ciclo lulopetista". Assim, trata-se de uma relação de acusação pautada nessa atribuição de culpa e responsabilidade pela corrupção aos governos anteriores, à esquerda, que é visto como um inimigo.

Montamos nossa equipe de forma técnica, sem o tradicional viés político que tornou o Estado ineficiente e corrupto. (BRASIL, BOLSONARO, 2019b, grifo nosso)

A corrupção, os privilégios e as vantagens precisam acabar. Os favores politizados, partidarizados devem ficar no passado, para que o Governo e a economia sirvam de verdade a toda a Nação. (BRASIL, BOLSONARO, 2019a, grifo nosso)

[...] o ostensivo processo de corrupção que, no ciclo lulopetista, dilapidou a riqueza nacional em balcões escusos de negócios. Ao leiloar, na bacia das almas da corrupção indiscriminada, os recursos da nação, tornou-se evidente o risco à sobrevivência das novas gerações, pois esse negativo fenômeno submergiu o país na maré do desemprego massivo, castigando duramente as famílias de mais de 14 milhões de brasileiros. (NOVA ESCOLA, RODRÍGUEZ, 2019, grifo nosso)

Ontem mesmo, verifiquei que o Brasil, apesar da Operação Lava-Jato e dos enormes esforços aqui e ali contra a corrupção, permanece em uma posição relativamente ruim nos índices de percepção quanto à existência de corrupção nos rankings anuais da Transparência Internacional.

[...] São necessárias políticas mais gerais contra a corrupção, com leis que tornem o sistema de Justiça mais eficaz e leis que diminuam incentivos e oportunidades contra a corrupção. Um juiz em Curitiba pouco pode fazer a esse respeito, no âmbito de políticas gerais, mas no governo federal a história pode ser diferente.

[...] a missão prioritária dada pelo Sr. Presidente Jair Bolsonaro foi clara, o fim da impunidade da grande corrupção (...) (ESTADÃO, MORO, 2019, grifo nosso) 
Embora o discurso do ministro Sérgio Moro empregue intensamente o termo corrupção, não há uma atribuição clara ao adversário ante às escolhas textuais. Não obstante, o texto emprega expressões como "Operação Lava-Jato", "enormes esforços (...) contra a corrupção" e "juiz em Curitiba". Esses termos acionam a imagem que o próprio ministro carrega consigo, como o juiz de Curitiba que empreendeu esforços na Operação Lava-Jato, sendo responsável pela prisão do ex-presidente Luiz Inácio Lula da Silva. Essa imagem converge $\mathrm{n}$ discurso com a instituição de uma missão prioritária atribuída pelo presidente Bolsonaro em combater a corrupção. Trata-se de uma imagem bem específica, mas que possui uma coerência no conjunto dos textos, contribuindo para designar a corrupção no âmbito dos governos anteriores, em especial, governos Lula.

A segunda faceta do estatuto do adversário é a vinculação dele com a dimensão intertextual de ordem religiosa-cristã, de modo que o seu estatuto é condizente com o pecado e o mal. A partir de fragmentos intertextuais do campo religioso, os discursos conferem o estatuto de pecador ao adversário, à medida que se sucede à sua demonização, como nas expressões de ideologias perversas e nefastas, e na encenação de narrativas de libertação da nação de inimigos com a interação entre o político e alusões bíblicas. Vimos, anteriormente, que ideologias correspondem a valores e ideais (globalismo, marxismo cultural, pensamento gramsciano) e agendas e pautas (ideologias de gênero, aborto) atribuídas à esquerda e que isso implica em um jogo de oposições. Logo, a esquerda (o adversário), tal como representada nos textos, é pecadora, é o próprio mal.

Ao analisar esses trechos e a constituição do outro como esse inimigo que deve ser combatido e aniquilado, é possível notar que se trata de uma relação política em construção a partir de identidades que não estão dadas previamente. O antagonismo permite a formação de identidades políticas (MENDONÇA, 2012a; 2012b). Segundo Chantal Mouffe (2015), a criação de uma identidade implica em estabelecer diferenças com outras identidades. Na construção de identidades coletivas, cria-se um "nós" cuja condição de existência é a demarcação de um "eles". Nem sempre essa relação "nós/eles" é uma relação de amigo/inimigo, mas, em muitos casos, o antagonismo estrutura-se justamente a partir de um "nós/eles" em que o "eles" estaria questionando a identidade e ameaçando a existência do "nós" (MOUFFE, 2015). É o que se vê quando o "eles" é referido como este mal que deve ser extirpado em benefício da nação.

Além disso, essa jornada bíblica entrelaçada intertextualmente com o posicionamento político do governo, que nos textos advoga em prol de um nacionalismo, concebe o estatuto do sujeito enunciador, o governo, como um "novo e restaurador governo", um "novo momento", uma "nova Independência". Os valores nacionalistas e patrióticos exaltados nos textos contribuem para validar positivamente o estatuto do governo em conduzir as transformações necessárias por meio daquela jornada. Os textos mobilizam uma figura específica com uma corporalidade física, um indivíduo, responsável por levar um projeto de governo restaurador. O presidente representa a figura de um profeta ou messiânico, pois ele está travando tal jornada para "libertar e reconquistar o Brasil", portando a palavra divina e a verdade. Em tais discursos, a "pregação moralizante" do presidente estaria colocando a sua própria vida em perigo - uma referência direta aos acontecimentos do atentado de Juiz de Fora. O lugar da nação e do Brasil, por sua vez, é representado similar ao da Terra Prometida do Êxodo do Velho Testamento, sendo "terras férteis abençoadas por Deus" que dependem de libertação ante um inimigo que as ocupa.

Por conseguinte, esses discursos legitimam o estatuto do governo mediante a vinculação do institucional com o religioso. A figura do presidente Bolsonaro desempenha um papel importante dentro desse estatuto, ao portar a palavra divina e a verdade, ou seja, o seu dizer deve ser ouvido e cumprido pela sociedade brasileira. Igualmente, o pressuposto trazido com o jogo de oposição com base nessa moralidade cristã é a instauração de polarizações, pois se o governo Bolsonaro se encontra do lado da verdade, aqueles que se encontram no lado oposto, como a ideologia de esquerda, estão com a mentira, trazendo, ainda, um efeito de sentido em forma de mensagem: "Deus abomina a mentira, Deus abomina a esquerda". O estatuto do governo, por seu turno, é visto como detentor de um divino propósito na libertação e reconstrução da nação por intermédio da Palavra e da verdade. No 
discurso do ministro Ernesto Araújo, temos, inclusive, um intertexto bíblico ("Conhecereis a verdade e a verdade vos libertará”), o qual sustenta e atrela toda essa construção narrativa de um imaginário político a textos bíblicos.

O estatuto do sujeito enunciador, tomando esse como o governo Bolsonaro, conduz a um destinatário que compartilha a mesma visão e que possa julgar positivamente aquele. O destinatário principal trazido nos textos é o povo brasileiro, grande público desses discursos, visto que um discurso de posse, enquanto discurso político, objetiva transmitir os primeiros relatos do projeto político do governo à sociedade, o povo brasileiro. Todavia, isso não quer dizer que não haja outros destinatários nos textos analisados, como o empresariado, o agronegócio exportador, os parlamentares etc. De todo modo, o povo brasileiro é citado em praticamente todos os discursos que mencionam a instituição da família.

Vamos unir o povo, valorizar a família, respeitar as religiões e nossa tradição judaico-cristã, combater a ideologia de gênero, conservando nossos valores.

(BRASIL, BOLSONARO, 2019b, grifo nosso)

Podemos, eu, você e as nossas famílias, todos juntos, reestabelecer padrões éticos e morais que transformarão nosso Brasil. (BRASIL, BOLSONARO, 2019a, grifo nosso)

Todos merecem oportunidade e apoio para cuidar de suas famílias seja qual for a sua configuração. (...) Nós somos família e todas as configurações familiares nesse Brasil serão respeitadas. (TV BRASILGOV, ALVES, 2019, grifo nosso)

[...] os valores culturais em que se sedimentam as nossas instituições mais caras: a família, a igreja, a escola, o estado e a pátria, numa clara tentativa de sufocar os valores fundantes da nossa vida social.

[...] é preciso também considerar que, sem o apoio das famílias, da sociedade, dos estados e dos municípios, nossas chances de sucesso diminuem significativamente.

(NOVA ESCOLA, RODRÍGUEZ, 2019, grifo nosso)

[...] a luta pela nação é a mesma luta pela família e a mesma luta pela vida, a mesma luta pela humanidade em sua dignidade infinita de criatura. (BRASIL, ARAÚJO, 2019, grifo nosso)

Em outras palavras, o destinatário (a sociedade brasileira) é valorizado enquanto um estatuto de família, para o qual são transmitidos sentidos de proteção/cuidado e necessidade de apoio. $\mathrm{O}$ estatuto do destinatário é tão valorizado nesses textos que é representado tanto como uma luta pela nação, e até luta pela humanidade. A família é aliada aos valores e às tradições compartilhadas pelo governo, como aqueles de ordem religiosa-cristã ("valorizar a família, respeitar as religiões e nossa tradição judaico-cristã"; "nossas famílias... restabelecer padrões éticos e morais"; "nossas instituições mais caras: a família, a igreja..."), de modo que a sustentação do governo não ocorre sem o aparato da família ("sem o apoio das famílias... nossas chances de sucesso diminuem significativamente"). Como esse estatuto do destinatário, visto como família, é incorporado pelos discursos ao estatuto do governo pelo compartilhamento de valores, a ameaça do adversário ao governo é uma ameaça também às famílias, afinal, a jornada e a transformação que os textos incubem ao governo é direcionado ao seu público, ao seu destinatário. Assim, esses discursos de medo e de inimigo mobilizam e retomam valores da família tradicional, como ordem, autoridade e moral (SOLANO, 2019b). A partir disso, temos o fomento de uma polarização (uns contra os outros), que deriva da combinação das relações de representação de aliança entre o estatuto do governo e o estatuto do destinatário e das relações de representação de oposição entre os estatutos do governo/família em relação ao estatuto do adversário. 


\section{OS ETHÉ NACIONALISTA E DE VIRTUDE DO GOVERNO BOLSONARO E AS RELAÇÕES DE PODER NA BUSCA POR LEGITIMIDADE}

O ethos do governo Bolsonaro é integrado pelas categorias linguístico-discursivas citadas anteriormente. Inicialmente, podemos argumentar que o ethos se constitui não só a partir das análises aqui feitas dos discursos de posse, mas também de um ethos pré-discursivo, entendido como uma imagem formada a partir de representações prévias, anteriores até mesmo aos atos de enunciação. No caso, muito antes dos discursos de posse, os discursos do então candidato Jair Bolsonaro já mobilizavam estereótipos ligados ao conservadorismo e ao nacionalismo, que acabaram por compor sua base eleitoral durante a campanha. No mesmo sentido, durante as eleições, tais discursos já vinham mobilizando um antagonismo com o mal, representado pela esquerda e, sobretudo, pelo candidato do Partido dos Trabalhadores, sempre colocados como a grande encarnação de tudo aquilo que possuía uma conotação negativa, como a corrupção, a oposição aos valores cristãos etc. Nos discursos de posse, como visto, esses elementos foram reiterados de alguma forma, em continuidade com uma imagem que já vinha sendo construída, mas agora constituindo o ethos do próprio governo Bolsonaro.

Assim, os fragmentos intertextuais de cunho religioso, a interação dos estatutos dos sujeitos discursivos, a mobilização de temas comuns e as escolhas linguísticas utilizadas através de vocabulário comum - que mesclam elementos do meio religioso-cristão com expressões de ordem patriótica - constituem os ethé nacionalista e de virtude do governo. Conforme Charaudeau (2018), o ethos de virtude corresponde à construção de imagens virtuosas que supõem que o político, ou, no nosso caso o governo, demonstre sinceridade e fidelidade acrescidas na imagem de honestidade pessoal. Ademais, Charaudeau (2018) explica que esta imagem remete à retidão e à sinceridade, ao passo que demonstra não participar de negócios escusos e mostra engajamento político não motivado por uma ambição pessoal, tendo em vista se tratar de um ethos que se faz acompanhar por uma atitude de respeito para com o cidadão. No que concerne ao ethos nacionalista, Irineu e Souza (2015) descrevem que ele é caracterizado por expressões que louvam signos identitários nacionais, apresentando ares ufanistas de exaltação à imagem nacional brasileira, a partir de um tom eminentemente patriótico, e também mediante críticas que se faz aos problemas sociais ou aos que se mostram contrários ao governo.

No caso dos textos analisados, é dito explicitamente que o governo possui uma "visão religiosa do mundo" e busca "respeitar as religiões" e as "tradições judaico-cristãs", além de instituir que a verdade, a palavra e a pregação estão sob o jugo do governo, tanto por meio de metáforas quanto referências a outros contextos de falas (como na forma de intertexto ou da intertextualidade). Em face disso, o ethos dito de virtude é constituído, à proporção que o sujeito enunciador tomado pelo governo - diante dos distintos representantes políticos que compartilham de uma mesma opinião - evoca, direta ou indiretamente, uma maneira específica de dizer sobre si mesmo. Esta maneira específica de dizer sobre si mesmo aciona valores morais de ordem religiosa-cristã e, por conseguinte, tenciona na demonstração de retidão em conduzir a si próprio, bem como na demonstração de fidelidade, que no caso é com Deus, com as famílias e o povo. Da mesma forma, a valorização de uma honestidade pessoal do governo é estabelecida nos textos de duas formas: de um lado, através da exaltação da nação e da pátria, já que são anunciados certos valores pautados na tradição e no patriotismo e em um posicionamento de direita, e, também, na representação da vitória do governo nas eleições, por exemplo, como uma "nova Independência"; e, de outra parte, por meio de uma clara relação de antagonismo com adversários, retratados como corruptos, visto que temos não apenas oposições, mas a acusação do crime de corrupção aos que ocuparam em momento anterior o atual governo. Constitui-se, assim, um ethos dito nacionalista.

Os ethé mostrados também são constituídos como nacionalista e de virtude. Em primeiro lugar, os textos, de distintas maneiras, mostram um tom através de escolhas linguísticas que buscam atestar o dizer ao atribuir uma autoridade ao que é dito. A atribuição de autoridade ocorre através de dois modos: a) uma institucional, já que os discursos articulam textualmente em conferir um estatuto de 
governo legítimo eleito pelo povo, como nas expressões "mandato a mim confiado pela vontade soberana do povo brasileiro", "em seu discurso de vitória" (traz o pressuposto de que a vitória decorreu das eleições), "a voz das ruas e das urnas foi muito clara", "ganhou, honrosamente e com grande margem de votos, as eleições presidenciais" - ou seja, os textos estabelecem o resultado das eleições como legítimo; e b) uma divina, pois além de invocar Deus para suplicá-lo ("Peço ao bom Deus que nos dê sabedoria para conduzir a nação"; "Que Deus abençoe esta grande nação"; "Que Deus nos ajude nesta empreitada"), confere uma missão divina ao governo na busca da libertação da nação e no combate às ideologias perversas e nefastas, isto é, o pecado.

Volto a esta Casa, não mais como deputado, mas como Presidente da República Federativa do Brasil, mandato a mim confiado pela vontade soberana do povo brasileiro.

(BRASIL, BOLSONARO, 2019b, grifo nosso)

As eleições deram voz a quem não era ouvido. E a voz das ruas e das urnas foi muito clara. $\mathrm{E}$ eu estou aqui para responder e, mais uma vez, me comprometer com esse desejo de mudança. (BRASIL, BOLSONARO, 2019a, grifo nosso)

O nosso bravo capitão Jair Messias Bolsonaro sobreviveu ao cruel atentado e, nos braços do povo que o apoiou desde o início, ganhou, honrosamente e com grande margem de votos, as eleições presidenciais, fazendo com que a data de 28 de outubro de 2018 seja lembrada pelo povo brasileiro como o dia da redenção de nosso país.

(NOVA ESCOLA, RODRÍGUEZ, 2019, grifo nosso)

Nós vamos também libertar a política externa brasileira, vamos libertar o Itamaraty, como o presidente Bolsonaro prometeu que faríamos, em seu discurso de vitória.

(BRASIL, ARAÚJO, 2019, grifo nosso)

Em segundo lugar, este tom permite mostrar a construção da representação de um corpo e um caráter correspondente ao sujeito enunciador, ao governo Bolsonaro. No caso do corpo conferido ao governo, esse se move no espaço social como um guerreiro de Deus, afinal, ele se encontra em uma batalha entre o bem e o mal para a libertação da nação, essa retratada como "terras férteis abençoadas por Deus", e, que, como visto anteriormente, a nação se encontra ocupada por inimigos, por pecadores. O sentido de um corpo enunciante de guerreiro, constituído subjetivamente nos/pelos textos, depende tanto da relação de oposição com o adversário, o inimigo a ser combatido e aniquilado, quanto da incorporação do destinatário, a família, que contribui para esse olhar, ao passo que compartilha de valores comuns.

Figura 1 - Ethé ditos e mostrados do governo Bolsonaro

\section{ethé ditos nacionalista e de virtude}

\section{ethé mostrados nacionalista e de virtude}

\footnotetext{
maneira específica de dizer sobre si mesmo:

- valores de ordem religiosa-cristã

- exaltação à nação e patriotismo

- posicionamento de direita

- contraposição ao adversário
}

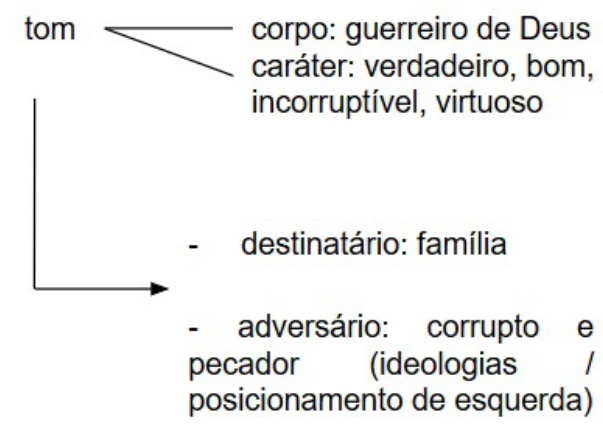


O caráter, por sua vez, corresponde aos traços psicológicos de ordem moral religiosa-cristã permeada através de certos valores encontrados nos textos, já abordados várias vezes (portador da Palavra e verdade, defesa da família, etc.), que agem para endossar seu olhar perante o destinatário, bem como se aproximar desse. Mas o caráter também diz respeito ao chamamento do adversário nos textos para caracterizá-lo não só como pecador em torno da expressão ideologia, mas, ainda, como corrupto, pois os textos trazem não apenas uma preocupação com a corrupção e a criminalidade, como também instituem quem são os responsáveis por ela - com base em uma acusação - mediante a desvalorização estereotipada dos que estiveram antes no governo, a esquerda. Por efeito, como os textos trazem o governo em oposição ao adversário, que é corrupto, pecador, mal, nefasto, o caráter do governo é estabelecido como incorruptível, verdadeiro, bom e virtuoso nesta relação maniqueísta que joga com estereótipos, se recusando, assim, a participar do mesmo domínio pecaminoso do adversário. A Figura 1 ilustra esses elementos que compreendem os ethé nacionalista e de virtude do governo Bolsonaro.

Direcionando a atenção para a questão da legitimidade, "o direito do sujeito de dizer ou de fazer" (CHARAUDEAU, 2018, p. 67), ela é conferida nestes textos à medida que o corpo enunciante e sua respectiva voz se deslocam no espaço social contido no domínio discursivo. Ou seja, durante o processo em que aqueles ethé do governo são constituídos e representados nos/pelos discursos, a legitimidade também é conferida ao governo. Essa relação encontra-se permeada por um processo interativo de influência sobre o destinatário (o público), porquanto as relações textuais agem para o reconhecimento do destinatário pelo enunciado (o governo), motivo pelo qual o uso do termo família - com seus distintos significados, como valorizar, proteger e cuidar da família, bem como solicitar o seu apoio para sustentar o governo - aciona no destinatário um efeito de sentido de afetividade, de se sentir próximo ao enunciador.

Esse processo incide numa incorporação do destinatário pelo enunciador e o efeito de sentido de afetividade trabalha conjuntamente com os valores representados nos discursos, como tradição, pátria, liberdade, e todos aqueles de ordem religiosa-cristã, de maneira que se pressupõem que tais valores sejam aceitos por todos. Consequentemente, os efeitos de influência advindos de estratégias de persuasão conduzidas ao destinatário visam conferir a legitimidade do sujeito enunciador, do governo, e a constituição e representação dos ethé nacionalista e de virtude possuem enorme importância, pois endossam a valorização de uma particular imagem do governo Bolsonaro.

Contudo, a influência sobre o destinatário não opera apenas no sentido de compartilhar valores com o enunciador, de se sentir próximo durante a ativação de uma afetividade. Ela opera, ainda, na legitimação da oposição, da acusação e da polarização político-ideológico do atual governo em uma relação de antagonismo com os representantes políticos e as ideologias de esquerda (marxismo cultural, socialismo, globalismo) instituídas nos textos como um mal, um pecado, a ser repudiado e combatido. $\mathrm{O}$ "antagonismo é uma forma de identificação", pois "o outro antagonizado faz parte do processo de significação" em que sentidos antagônicos a ele são constituídos, ao passo que dicotomiza o espaço social (MENDONÇA, 2012b, p. 223-224). Portanto, da relação de antagonismo com o outro, os sentidos constituídos permitem que o destinatário se identifique com o governo, uma vez que o adversário foi convertido à figura de inimigo.

A invocação do outro nos discursos, através da criação de simulacros de seus posicionamentos políticos e ideológicos, como a bandeira da ideologia de gênero e do aborto, opera para a desconstrução da esquerda por intermédio da instauração da polêmica e da estratégia discursiva de oposição. Tais sujeitos discursivos, o governo e o adversário, são posicionados com base em diferenças no interior de um maniqueísmo religioso-cristão do bem versus mal. Aliado a isso, temos a presença da estratégia discursiva de acusação que se manifesta pela atribuição de culpa e da responsabilidade pela corrupção aos governos anteriores, à oposição política. Soma-se a isso, ainda, a estratégia discursiva de polarização, haja vista que a enunciação funda uma situação conflituosa de uns em relação aos outros, em que o sujeito enunciador (o governo) e o sujeito destinatário (o povo, a família) encontram em posição de defesa e combate em relação ao sujeito adversário (a esquerda, a oposição política), 
uma vez que os textos articulam um sentido de ameaça, portanto, se torna necessário anular o outro em um jogo de dominação. Todas essas estratégias se dão a partir de uma relação de antagonismo entre interior/exterior, em que a presença de um outro, o adversário, impede a constituição do eu mesmo (MENDONÇA, 2012a), o governo Bolsonaro.

Ademais, a combinação dessas distintas estratégias discursivas, a invocação de toda uma moralidade cristã que dialoga com o campo político nacionalista e conservador, bem como a apresentação de uma pauta do combate à corrupção faz parte, nesses discursos, de um jogo de relações de força em que tais discursos buscam impor uma determinada visão de mundo. A imposição de uma particular visão de mundo pelo sujeito enunciador repousa numa específica conjuntura sócio-histórica: a busca por pela legitimidade para sustentar o poder conquistado perante eleições conturbadas e uma campanha eleitoral que recebeu muitas críticas pela oposição política/esquerda; afinal, a plataforma política da campanha de Bolsonaro foi vista como regressiva em termos de direitos humanos e de minorias, e da celebração de práticas e políticas do regime ditatorial-militar, entre outros pontos.

Portanto, a busca por legitimidade que permeia esses discursos é também uma disputa por poder e espaço político diante de relações de forças e jogo de dominação do outro; isso porque, os discursos de posse mobilizam estratégias discursivas de oposição, acusação e polarização político-ideológica para endossar a viabilização do poder, isto é, o "agir sobre o outro", a legitimidade, e de toda e qualquer ação política que se possa desempenhar durante o governo.

A Figura 2 sintetiza todo esse processo discursivo que abarca as estratégias discursivas e a atribuição de legitimidade ao governo Bolsonaro pelos discursos, ao passo que constitui e representa os ethé nacionalista e de virtude.

Figura 2 - Ethé do governo Bolsonaro, estratégias discursivas e legitimidade

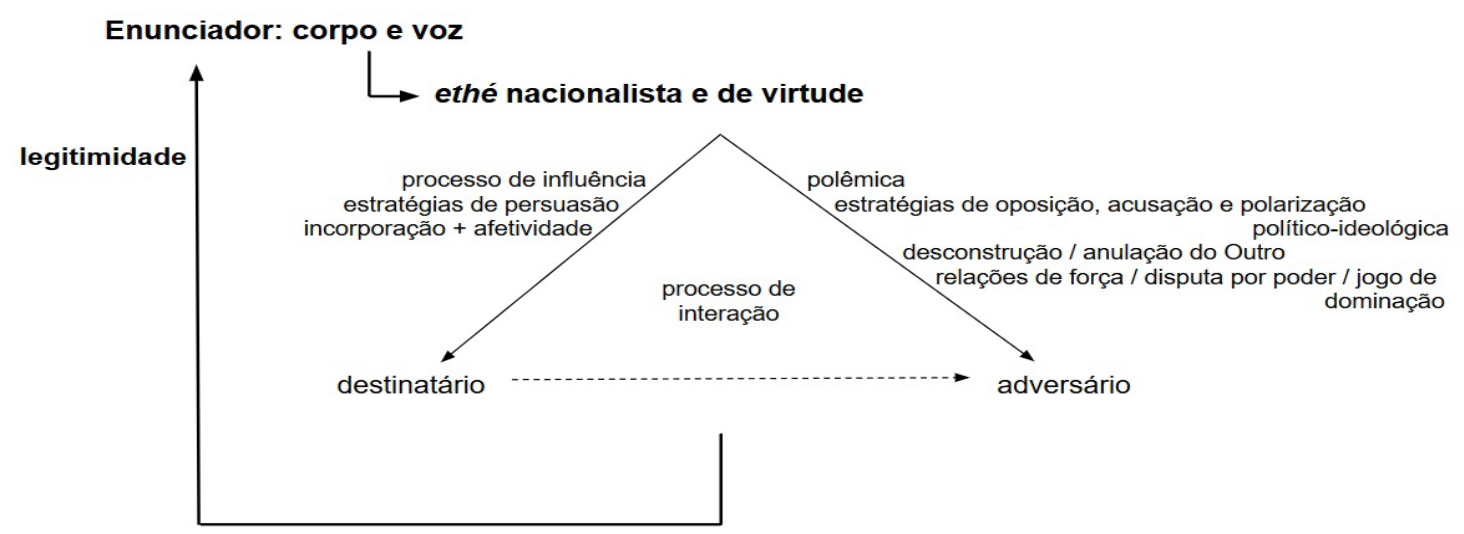

Figura 2 - Ethé do governo Bolsonaro, estratégias discursivas e legitimidade

\section{CONSIDERAÇÕES FINAIS}

Esse artigo focou em realizar uma análise dos discursos de posse proferidos pelo presidente Bolsonaro e quatro ministros do seu governo, de modo a verificar como as articulações textuais impulsionaram a busca pela legitimidade a partir da constituição e representação de determinado ethos do governo Bolsonaro. A análise do discurso empregada, pautada no dispositivo de análise da Semântica Global de Maingueneau, demonstrou que esses discursos políticos construíram uma relação específica que advogou um posicionamento discursivo nacionalista, identificado com o espectro político-ideológico da direita, ao mesmo tempo em que contribuiu para uma filiação intertextual com o discurso religioso-cristão. 
Cada faceta da relação encontrada esteve permeada por sentidos e efeitos de persuasão diante de certos sistemas de significados mobilizados a fim de influenciar o destinatário, isto é, o público constituído pelo povo brasileiro representado a partir das famílias. Com exceção do discurso de Sérgio Moro, o ethos do governo Bolsonaro foi constituído e representado coletivamente pela base do alto escalão no início de sua gestão conforme os textos sinalizam e constroem determinados sentidos comuns compartilhados por esses representantes. Os textos articulam uma exaltação à imagem nacional brasileira mediante a mobilização de signos identitários como defesa da pátria, defesa da liberdade, patriotismo, defesa da tradição. Esses ideais apelam não somente para um sentimento de pertencimento à nação; mas também para a atribuição de culpa e responsabilidade pela corrupção no país e nas instituições, e o repúdio aos posicionamentos da esquerda, como as supostas defesas do aborto e da ideologia de gênero.

Por conseguinte, estabelece-se um efeito de sentido em que aqueles que compactuam com tais valores, devem ser combatidos, já que nos discursos o governo se encontra nessa posição. Essa relação textual converge para a constituição de um ethos nacionalista do governo, com atributos do conservadorismo de direita. Complementarmente, os textos também articulam sentidos através de alusões bíblicas e moral cristã. Ainda, é encenada uma batalha entre o bem e o mal, sendo a esquerda representada como uma inimiga da nação, além de compartilhar um estatuto de pecadora. Essa relação intertextual impulsiona a constituição de um ethos de virtude do governo. Finalmente, neste mesmo processo de constituição e representação desses ethé do governo, um conjunto de estratégias discursivas se manifestou através desta relação de aliança entre os campos político e religioso.

Depreende-se, então, que os discursos, ao imporem uma visão global, trouxeram efeitos de sentido que buscam estabelecer determinados ideais, conforme a manipulação de opiniões, posicionamentos e estereótipos por meio da utilização de estratégias discursivas tanto de persuasão para provocar uma influência no destinatário quanto de oposição, acusação e polarização do sujeito adversário, a esquerda. Dessa forma, estes discursos políticos analisados mostraram que "Brasil acima de tudo, Deus acima de todos" é o endosso antidemocrático para legitimar a dominação ao diferente, principalmente no pensar. Reforçamos que os sentidos pincelados e os ethé do governo reconhecidos foram constituídos e representados nos/pelos discursos. A exceção a toda essa lógica é o discurso do ministro Sérgio Moro, sendo um potencial quadro para futuras análises.

Por fim, gostaríamos de encerrar a discussão apontando que a análise do discurso não esgotou a leitura e a interpretação de todos os sentidos e ethé do governo, podendo surgir muitos outros. Com base em nossas escolhas teóricas e metodológicas, esperamos que nossa modesta análise possa contribuir para demonstrar à Ciência Política o quanto o estudo do discurso é de suma importância para compreender como a vida social e a ação política são motivadas e orientadas pelos discursos. Afinal, os discursos políticos constituem uma questão de poder e é por intermédio deles que se atribuem sentidos para a política, sendo eles próprios uma maneira de se fazer política, tendo, por decorrência, implicações no cotidiano e no cenário político. 


\section{Referências}

AMOSSY, Ruth. Introdução: da noção retórica de ethos à análise do discurso. In: Amossy, R. (org.), Imagens de si no discurso: a construção do ethos. 2. ed. São Paulo: Contexto, 2019, p. 9-28.

BRASIL. Ministério das Relações Exteriores. Discurso do ministro Ernesto Araújo durante cerimônia de posse no Ministério das Relações Exteriores. Brasília, 2 jan. 2019. Disponível em: <http://www.itamaraty.gov.br/pt-BR/discursos-artigos-e-entrevistas-categoria/ministro-das-relacoes-exteriores-discursos/19907-discurso-do-ministro-ernesto-araujo-durante-cerimonia-de-posse-no-ministerio-das-relacoes-exteriores-brasilia-2-de-janeiro-de-2019>. Acesso em: 2 fev. 2020 .

BRASIL. Presidência da República. Discurso do Presidente da República, Jair Bolsonaro, durante cerimônia de recebimento da Faixa Presidencial. Brasília, 1 jan. 2019a. Disponível em: < https://www.gov.br/planalto/pt-br/acompanhe-o-planalto/discursos/2019/discurso-do-presidente-da-republica-jair-bolsonaro-durante-cerimonia-de-recebimento-da-faixa-presidencial>. Acesso em: 14 dez. 2019.

BRASIL. Presidência da República. Discurso do Presidente da República, Jair Bolsonaro, durante cerimônia de posse no Congresso Nacional. Brasília, 1 jan. 2019b. Disponível em: <https:/www.gov.br/planalto/pt-br/acompanhe-o-planalto/discursos/2019/discurso-do-presidente-da-republica-jair-bolsonaro-durante-cerimonia-de-posse-no-congresso-nacional>. Acesso em: $14 \mathrm{dez} .2019$.

CHARAUDEAU, Patrick. 2014. Linguagem e discurso: modos de organização. 2. ed. São Paulo: Contexto, 2014.

CHARAUDEAU, Patrick. 2016. A conquista da opinião pública: como o discurso manipula as escolhas políticas. São Paulo: Contexto, 2016.

CHARAUDEAU, Patrick. 2018. Discurso político. 2. ed. São Paulo: Contexto.

CHARAUdeaU, Patrick; MAINGUENEAU, Dominique. Dicionário de Análise do Discurso. 2. ed. São Paulo: Contexto, 2008.

DEBERT, Guita Grin. 2008. Ideologia e populismo: Adhemar de Barros, Miguel Arraes, Carlos Lacerda, Leonel Brizola. Rio de Janeiro: Centro Edelstein de Pesquisas Sociais. Disponível em:

$<$ http://books.scielo.org/id/b23ds>. Acesso em: 5 fev. 2020.

ESTADÃO. Política. Leia a íntegra do discurso de Moro ministro, 2 jan. 2019. Disponível em: <https://politica.estadao.com.br/blogs/fausto-macedo/leia-a-integra-do-discurso-de-moro-ministro/>. Acesso em: 5 fev. 2020.

IRINEU, Lucineudo Machado; SOUSA, Maria Margerete Fernandes de. Imagens de si projetadas no discurso jornalístico da América Latina: a tradição editorialística do Jornal do Brasil e do Clarín nos séculos XX e XXI. In: Letras de Hoje, v. 50, n. 4, p. 475-482, 2015. Disponível em: <http://revistaseletronicas.pucrs.br/ojs/index.php/fale/article/ view/20453/13821>. Acesso em: 09 jan. 2020.

MAINGUENEAU, Dominique. Novas tendências em análise do discurso. 3. ed. Campinas: Ed. Universidade Estadual de Campinas, 1997.

MAINGUENEAU, Dominique. Termos-chave da análise do discurso. 1. ed. Belo Horizonte: Ed. UFMG, 1998.

MAINGUENEAU, Dominique. Doze conceitos em análise do discurso. São Paulo: Parábola Editorial, 2010.

MAINGUENEAU, Dominique. Cenas da enunciação. 2. ed. São Paulo: Parábola Editorial, 2012.

MAINGUENEAU, Dominique. Análise de textos de comunicação. 6. ed. ampl. São Paulo: Cortez, 2013.

MAINGUENEAU, Dominique. A propósito do ethos. In: Motta, Ana Raquel; Salgado, Luciana. (orgs.), Ethos discursivo. 2. ed. São Paulo: Contexto, p. 11-29, 2014.

MAINGUENEAU, Dominique. Discurso e análise do discurso. 1. ed. São Paulo: Parábola Editorial, 2015. 
MAINGUENEAU, Dominique. Gênese dos discursos. 2. ed. São Paulo: Parábola Editorial, 2016.

MENDONÇA, Daniel de. Como olhar "o político" a partir da teoria do discurso. Revista Brasileira de Ciência Política, v. 1, p. 153-169. 2012a. Disponível em: <https://periodicos.unb.br/index.php/rbcp/article/view/1533>. Acesso em: 11 jul. 2020.

MENDONÇA, Daniel de. Antagonismo como identificação política. Revista Brasileira de Ciência Política, n. 9, set/ dez., p. 205-228, 2012b. Disponível em: <https://doi.org/10.1590/S0103-33522012000300008>. Acesso em: 11 jul. 2020 .

MOUFFE, Chantal. Sobre o Político. São Paulo: Editora WMF Martins Fontes, 2015.

NOVA ESCOLA. Discurso de Ricardo Vélez Rodríguez: que mudanças esperar no MEC. 3 jan. 2019. Disponível em: <https://novaescola.org.br/conteudo/14877/discurso-de-ricardo-velez-rodriguez-que-mudancas-esperar-no-mec $>$. Acesso em: 5 fev. 2020.

PINTO, Céli Regina Jardim. Elementos para uma análise de discurso político. Barbarói, v. 1, n. 24, p. 78-109, 2006. Disponível em: <http://dx.doi.org/10.17058/barbaroi.v0i0.821>. Acesso em 09 jan. 2020.

SILVEIRA, Hermínia Maria Martins Lima. Identidade, prática discursiva e construção do ethos do professor de língua portuguesa. Cadernos CESPUC, v. 1, n. 25, p. 16-26, 2014. Disponível em: <http://periodicos.pucminas.br/index.php/ cadernoscespuc/article/view/11085>. Acesso em 15 fev. 2020.

SOLANO, Esther. A bolsonarização do Brasil... In: ABRANCHES, Sérgio (et. al.) Democracia em risco? 22 ensaios sobre o Brasil hoje. São Paulo: Companhia das Letras, 2019a, p. 307-321.

SOLANO, Esther. "Eu voto no Bolsonaro porque ele vai mudar Brasil": escutando os eleitores de Bolsonaro. In: AVRITZER, Leonardo [et al.] Pensando a democracia, a república e o estado de direito no Brasil. Belo Horizonte: Projeto República, 2019b, p. 119-130.

TV BRASILGOV. Discurso da Ministra da Mulher, Família e Direitos Humanos, Damares Alves. Cerimônia de transmissão de cargo à Ministra da Mulher, Família e Direitos Humanos, Damares Alves. (31m18s), 2 jan. 2019. Disponível em: <https://youtu.be/2Qz_tS6zofg>. Acesso em: 15 dez. 2019.

$\begin{array}{cl}\text { Histórico } & \text { Recebido em: } 12 / 05 / 2020 \\ & \text { Revisão em: 05/08/2020 } \\ & \text { Aceito em: } 28 / 08 / 2020 \\ & \text { Concepção: JAS; ML } \\ & \text { Coleta de dados: JAS } \\ & \text { Análise de dados: JAS; ML } \\ & \text { Elaboração do manuscrito: JAS; ML } \\ \text { Contribuição } & \text { Revisões críticas de conteúdo intelectual importante: JAS; ML } \\ & \text { Aprovação final do manuscrito: JAS; ML } \\ & \\ & \text { Não houve financiamento }\end{array}$

